\title{
On the Feasibility of Economic Cooperation in East Asia: Perspectives from Trade Creation and Trade Diversion
}

\author{
Deng-Shing Huang and Jenn-Hwa Tu* \\ Institute of Economics, Academia Sinica
}

\begin{abstract}
This paper attempts to measure the feasibility of economic cooperation in East Asia from an economic point of view. To approach this issue, we decompose the effect of economic cooperation into trade creation (TC) and trade diversion (TD) by using the well-known revealed comparative advantage (RCA) index. Diversity in the RCA indices among member countries should be closely related to the magnitude of TC. On the other hand, TD occurs in the case of a union in goods in which the outside region as a whole has a comparative advantage. In addition, members who suffer from TD will be those that have a low RCA index and thus have to import.

The results show that the export structures differ quite significantly between ASEAN and the NICs. Based on the RCA index, we would expect an intraregional trade creation effect in the case of commodity groups 1 (agriculture), 2 (mining), 31 (food, beverages and tobacco), 32 (textiles), 33 (wood \& prod-

* Associate Research Fellows, Institute of Economics, Academia Sinica, Nakang, Taipei, Taiwan. The authors would like to thank participants in the Ninth ADIPA Conference on "The Changing World Community: Development Consequences and Adjustments in Asia and the Pacific," in Macau, 8-11 October 1991 and seminar participants at Academia Sinica. We are also indebted to an anonymous referee for helpful comments on an earlier version. Financial support from NSC, Taiwan, R.O.C., under grant NSC82-0301-H-001-002 is gratefully acknowledged.

C1994 - Institute for International Economics, Sejong Institution. All rights reserved.
\end{abstract}


ucts) and 39 (other manufactures) if ASEAN and the NICs form a union. Since Japan has a revealed comparative advantage in commodity groups 37 (basic metals) and 38 (metal manufactures), excluding it from the union would induce TD in these goods and the importing member countries will thus suffer.

Therefore, if Japan is included into the union, trade diversion in the case of goods 37 and 38 disappears, and trade creation follows. However, for goods 31 (food, beverages and tobacco), 34 (paper and products), and 35 (chemicals), in which these ten countries, as a whole, have a comparative disadvantage compared with the rest of the world, TD is inevitable. Again, countries that have to import or have a comparative disadvantage in these goods will suffer from trade diversion.

\section{Introduction}

Ever since the European Single Market Plan was initiated by the Executive Committee of the European Economic Community (EEC) in June 1985, the issue of regional economic cooperation has been the focus of attention in the international economic arena. Partly as a result of the European Single Market concept, the Canada-United States Free Trade Agreement was signed and became effective in January 1989. Furthermore, Canada, Mexico and the United States commenced negotiations on a North-American Free Trade Area agreement in June 1991. In addition to the moves towards cooperation that have taken place in North America, the pessimism surrounding the failure of the Uruguay Round of GATT negotiations to resolve the issue concerning the protection of agricultural products has led to a re-emergence of regional self-protective sentiment around the world. One area in which this has become particularly self-evident is Asia. The formation of a so-called East Asian Economic Grouping, or an East Asian Economic Community has been proposed by Malaysian prime minister Mahathir Mohamad.

Due to various economic and political considerations, the concept of an East Asian Economic Grouping is still under strict scrutiny by all the parties concerned. The extent to which an economic grouping can be successful depends mainly on the magnitude of the net economic gains to be derived 
by forming the block. Therefore, the feasibility of the East Asian Economic Grouping or how well it can possibly function in the future, if it is actually formed, can be roughly evaluated in terms of the potential economic gains and costs it can bring about, which is the main purpose of this paper. As for the structure of this paper, section II introduces various kinds of regional economic cooperation and their potential gains and costs. Section III describes current efforts at regional economic cooperation in Asia and the reason for considering a new economic grouping. Section IV introduces the concepts used in this paper to evaluate the feasibility of the proposed East Asian Economic Grouping. Section V gives details of the methodology and data used, and analyzes the results. Section VI concludes the findings.

\section{Regional Economic Cooperation and Its Effects}

As is well known, regional economic cooperation or integration may take one of various forms. ${ }^{1}$ These forms are usually classified into four groups: (i) a free-trade area, where member countries remove all trade barriers among themselves but retain their individual commercial policies toward the outside world, (ii) a customs union, which is similar to a free-trade area except that the member countries adopt common external commercial policies; (iii) a common market, which is a customs union that also aliows for free factor mobility within the market; and (iv) an economic union, which is a common market that seeks to achieve a complete unification of monetary and fiscal policies. In addition, there is also a monetary union. This lies in between a common market and an economic union.

The effects of regional economic cooperation, typically taking the form of a customs union, include the following static effects: (i) trade creation effects, deriving from both production and consumption gains; (ii) trade diversion effects, derived by replacing cheaper imports with those of the member countries, as a result of tariff discrimination; (iii) improved international bargaining power due to the larger economic size; (iv) decreased administrative expenditures among the member countries; (v) Less smug-

1. Although integration has stronger economic implications than cooperation, we do not practically differentiate between them in this paper. 
gling existing among the member countries. There are also the following dynamic effects: (a) higher production efficiency brought about by enhanced competition and thus specialization and resource relocation; (b) decreased average production cost due to economies of scale in a larger market; (c) higher international investment, resulting from an increase in investment opportunities and lower uncertainty and risks; and (d) enhanced technological change resulting from increased competition. All these factors lead to (e) faster economic growth.

Except for the trade diversion effect, all the effects support the notion of regional economic cooperation. However, interested parties may also be constrained by some other economic factors, such as: (i) a high tariff-revenue share in the government budget may discourage a government from joining in this kind of arrangement; (ii) a large trade deficit depresses the will of a government to risk a possibly deteriorating trade balance, resulting from tariff reduction or abolishment; (iii) the worry that unequal terms of trade or imperialistic opportunities may be further exploited by some powerful member country discourages other members from joining; ${ }^{2}$ and (iv) decreased trade policy independence may concern some developing countries which would like to pursue an independent development policy.

\section{Regional Economic Cooperation in Asia}

In Asia, there already exist several regional economic cooperation associations including (i) the Pacific Economic Cooperation Conference (PECC), (ii) the Pacific Trade and Development Conference (PAFTAD), (iii) the Pacific Basin Economic Council (PBEC), and (iv) the Pacific Telecommunications Conference (PTC). ${ }^{3}$ These associations, however, basically confine themselves to a cooperation conference, and lack real economic integration programs. An exception to these conferences is the well-known Association of South-East Asian Nations (ASEAN), including Indonesia, Malaysia, the Philippines, Singapore, Thailand and, since 1984, Brunei. Through the Preferential Trading Arrangements, ASEAN Industrial Projects and ASEAN

2. Refer to Ben-David [1991] for a detailed discussion about this point.

3. For a detailed description, please see El-Agraa [1989, p. 158]. 
Industrial Complementation, this association distinguishes itself from the other institutions.

Active as it may appear to be, ASEAN, in terms of its economic power, is still quite limited. As we can see in Table 1, in 1989, its share of world trade was merely 3.98\%. Even within Asia, the trade share of ASEAN was no more than 20\%. This will put ASEAN in a relatively disadvantageous position when the EEC Single Market and the North-American Free Trade Area are

Table 1

East Asia's Trading Power (1989)

\begin{tabular}{|l|r|r|r|r|r|}
\hline & $\begin{array}{r}\text { GNP } \\
\text { (US\$ b.) }\end{array}$ & $\begin{array}{c}\text { GNP per capita } \\
\text { (US\$) }\end{array}$ & $\begin{array}{r}\text { Exports } \\
\text { (US\$ b.) }\end{array}$ & $\begin{array}{r}\text { Imports } \\
\text { (US\$ b.) }\end{array}$ & $\begin{array}{r}\text { Total Trade } \\
\text { (US\$ b.) }\end{array}$ \\
\hline Brunei & - & - & 2.05 & 1.55 & 3.60 \\
Indonesia & 89.36 & 494 & 12.41 & 23.20 & 35.61 \\
Malaysia & 35.61 & 2,099 & 20.48 & 29.50 & 49.98 \\
Philippines & 44.25 & 736 & 11.78 & 9.06 & 20.84 \\
Singapore & 28.89 & 10,780 & 45.82 & 35.75 & 81.57 \\
Thailand & 68.77 & 1,240 & 22.43 & 20.73 & 43.16 \\
\hline ASEAN Total (1) & 266.88 & - & 114.97 & 119.79 & 234.76 \\
\hline Hong Kong & 37.43 & 9,605 & 69.82 & 47.69 & 117.51 \\
South Korea & 211.20 & 4,994 & 51.42 & 58.98 & 110.40 \\
Taiwan & 161.70 & 7,997 & 66.30 & 52.27 & 118.57 \\
Japan & $2,972.30$ & 24,026 & 186.91 & 294.87 & 481.78 \\
\hline East Asia Ten (2) & $3,649.51$ & - & 489.42 & 573.60 & $1,063.02$ \\
\hline Mainland China & 422.43 & - & 52.57 & 73.12 & 125.69 \\
\hline World Total & - & - & $2,902.60$ & $2,989.80$ & $5,892.40$ \\
Asia Total & - & - & 634.14 & 752.18 & $1,386.32$ \\
(1)/World Total & - & - & $3.96 \%$ & $4.01 \%$ & $3.98 \%$ \\
(1)/Asia Total & - & - & $18.13 \%$ & $15.93 \%$ & $16.93 \%$ \\
(2)/World Total & - & - & $16.86 \%$ & $19.19 \%$ & $18.04 \%$ \\
(2)/Asia Total & & & $77.18 \%$ & $76.26 \%$ & $76.68 \%$ \\
\hline
\end{tabular}

Notes: 1. Data for Brunei are derived by summing the third and fourth quarters of 1989 and the first and second quarters of 1990.

2. Asia Total includes the East Asia Ten, Mainland China, Pakistan and India.

3. Taiwan's GNP and GNP per capita refer to 1990.

Sources: 1. International Monetary Fund, Direction of Trade Statistics, March 1991.

2. International Monetary Fund, International Financial Statistics, 1990.

3. Council for Economic Planning and Development, Taiwan, ROC. 
formed. However, if ASEAN is enlarged to include Hong Kong, South Korea, Taiwan and Japan, as has often been suggested, the East Asia Ten will have an approximately one-fifth share of world trade, or a three-quarter share of Asian trade. This larger share will enable this group to negotiate economic or trade issues more effectively with the other regional economic powers. Such a prospect looks intuitively appealing and is thus attractive to all parties concerned.

\section{The Concepts for Feasibility Evaluation}

As mentioned earlier, the impacts of regional economic cooperation or integration are in general differentiated into two types, static effects and dynamic effects. Theoretical studies on this issue are tremendous. For example, the static impacts of customs unions have been tackled by Viner [1950], Gehrels [1956], Lipsey [1957], Melvin [1969] and Bhagwati [1971], etc. Furthermore, Yu and Scully [1975] and Yu [1981, 1982] have studied the impacts of customs unions in the presence of labor market distortions characterized by general unemployment. Richard and Wang [1988] has extended the studies to the case of urban-unemployment. Another stream of studies considers the dynamic effects of customs union including economics of scale, technical change, increased competition and changes in the investment pattern, e.g., Scitovsky [1958], Balassa [1961], Kreinin [1964], Scully and Yu [1974], Chacholiades [1978], Choi and Yu [1984], Yu [1985] and Patterson [1986] Miyagiwa and Young [1986], just to name a few.

This paper adopts Viner's static approach by comparing the trade creation effects (TC) with the trade diversion effects (TD) resulting from the formation of a customs union. However, this approach is a purely static one in the sense that many dynamic effects, e.g., scale economies and intra-industry trade, are excluded from discussion.

According to Viner's traditional wisdom, trade creation refers to the substitution of expensive domestically-produced goods by cheaper imports from the members of the customs union and is thus regarded as a welfare improvement. Trade diversion, however, involves the replacement of cheaper initial imports from the non-member countries by more expensive imports from the member countries, which may be interpreted as a welfare 
loss. If the productive activities of the member countries are basically complementary, or vertically in line with one another, the trade creation effects should be greater. Conversely, where there are competing industries in member countries, the trade creation effects will be smaller.

As will be seen in what follows, the so-called revealed comparative advantage (RCA) concept is used to measure the comparative advantage of each industry in each country. The idea is that the more dispersedly distributed are the comparative advantages among the member countries, the greater will be the possibility of these countries complementing each other's industrial production. Therefore, ceteris paribus, if the variance of the RCA's of the member countries in one industry is large, the TC effects in that industry should also be large. Conversely, a smaller variance of the RCA's would suggest a smaller TC effect. Furthermore, ceteris paribus, a large difference in the RCA's of the member and non-member countries would imply a larger TD effects since more imports originally coming from non-member countries would be replaced by imports from the member countries. The RCA variance among the member countries is therefore used to evaluate the TC effects among them and the RCA difference between this group and the outside world is used to evaluate the TD effects. The feasibility or potential of this grouping depends, of course, on the net difference between TC and TD.

\section{On the Measurement of TC and TD}

As mentioned earlier, the dispersion of the RCA's among the member countries are used to measure the magnitude of $\mathrm{TC}$ and the difference in RCA's between the selected group and the rest of the world is used to determine the magnitude of TD. In what follows, we will explain the relationship between the RCA index and TC or TD in more detail.

\section{A. The RCA index and TC and TD}

Trade creation denotes a shift in production from higher-cost domestic producers to cheaper producers in the partner country. Trade diversion, on the contrary, represents a shift from lower-cost producers in the non-member countries to higher-cost producers within the group due to discriminato- 
ry trade policies against non-member countries. Thus, trade creation is equivalent to an increase in intra-regional trade and trade diversion to a decrease in inter-regional trade.

Based on the traditional wisdom, we know that the volume of trade will be larger if the variance of the comparative advantage is higher. Thus we can use the difference in the comparative advantage to predict the inter-regional trade diversion as well as the trade creation resulting from the formation of a union. Intuitively, larger differences in the RCA's within the union region represent a larger TC effect. Similarly, the reduction in the inter-regional volume of trade or the TD effect will be greater if the differences in RCA's between the union region and the rest of the world are higher.

\section{RCA Index:}

There are several RCA indices referred to in the literature. ${ }^{4}$ For convenience, we adopt the index used in Hou \& Wang [1991], in which the RCA is defined as the ratio of the share of a commodity group in total exports for a country or group of countries to that commodity group's share of world exports. A country is said to have a revealed comparative advantage in good $i$ if its export share of good $i$ is higher than the world average, i.e. the RCA index of good $i$ for the country is greater than one. On the contrary, the country is said to have a revealed comparative disadvantage in good $i$, if the corresponding RCA index is less than one.

For convenience, the above RCA concept may be restated by using the following notation. Let $X_{k}^{i}$ denote the value of exports of good $i$ from country or region $k$. Therefore,

$$
X_{k} \equiv \sum_{i} X_{k}^{i}
$$

represents the total export value of country or region $k$. And,

$$
S_{k}^{i} \equiv \frac{X_{k}^{i}}{X_{k}}
$$

is the share of commodity group $i$ in the total exports for country or region k. Obviously, 


$$
X^{i} \equiv \sum_{k} X_{k}^{i}
$$

would be the total exports of good $i$ in the world, and

$$
X \equiv \sum_{i} X^{i}
$$

represents total exports in the world. Then,

$$
S^{i} \equiv \frac{X^{i}}{X}
$$

depicts the $i$ th commodity group's share of the world exports, and the RCA index may be obtained by means of the following formula:

$$
R C A_{k}^{i}=\frac{S_{k}^{i}}{S^{i}}
$$

$R C A_{k}^{i}>1$ means that country $k$ or region $k$ has a revealed comparative advantage in good $i$. On the contrary, $R C A_{k}^{i}<1$ states that the country has a revealed comparative disadvantage in good $i$. Furthermore, the larger the deviation of the RCA index from one, the greater the comparative advantage or disadvantage.

\section{Data Sources}

To calculate the RCA index we need the shares of various commodity groups in the total exports of the world and the shares in terms of total exports of a country or groups of countries. The data used originate from the following three sources:

1. United Nations, Yearbook of International Trade Statistics (Volume 1), Special Table, 1987.

2. United Nations, Yearbook of International Trade Statistics (Volume 1), Country Tables, 1979, 1982, 1987.

3. Taiwan Statistical Data Book, Council for Economic Planning and Development R.O.C., 1989

By using the U.N.'s country tables (source 2), we are able to get the data for each country's export share of a given commodity group, $S_{k}^{i}$. With $S_{k}^{i}$ and by making use of the total export value of a country, $X_{k}$, from data source 1 , we are able to calculate the share of the same grouping in total 
Table 2

Share of Commodity Groups in a Country's Exports

\begin{tabular}{|c|c|c|c|c|c|c|c|c|c|c|c|c|}
\hline & $\begin{array}{c}\text { Good } \\
\text { ntries }\end{array}$ & 1 & 2 & 31 & 32 & 33 & 34 & 35 & 36 & 37 & 38 & 39 \\
\hline \multirow{10}{*}{1973} & Indonesia & 38.80 & 44.50 & 4.00 & 0.20 & 0.60 & 0.00 & 7.50 & 0.00 & 3.00 & 1.10 & 0.30 \\
\hline & Malaysia & 52.00 & 3.30 & 9.80 & 1.60 & 11.50 & 0.20 & 4.00 & 0.20 & 12.50 & 4.20 & 0.70 \\
\hline & Philippines & 33.70 & 18.20 & 28.40 & 2.30 & 7.70 & 0.70 & 1.50 & 1.40 & 0.60 & 0.70 & 4.60 \\
\hline & Singapore & 23.00 & 0.70 & 6.10 & 7.90 & 6.20 & 1.00 & 24.70 & 0.40 & 1.40 & 25.90 & 2.70 \\
\hline & Thailand & 47.50 & 4.20 & 20.90 & 8.60 & 2.90 & 0.20 & 2.10 & 1.20 & 7.00 & 0.90 & 4.60 \\
\hline & Brunei & 0.10 & 97.70 & 0.00 & 0.00 & 0.10 & 0.00 & 2.10 & 0.00 & 0.00 & 0.00 & 0.00 \\
\hline & Hong Kong & 0.90 & 0.60 & 1.10 & 51.60 & 0.40 & 1.10 & 4.80 & 0.30 & 0.50 & 23.00 & 15.80 \\
\hline & Korea & 6.00 & 1.40 & 3.50 & 42.70 & 10.40 & 1.50 & 5.30 & 1.40 & 6.10 & 16.60 & 5.00 \\
\hline & Taiwan & 4.35 & 0.13 & 9.75 & 27.68 & 4.24 & 7.67 & 1.74 & 1.12 & 1.76 & 2.03 & 39.53 \\
\hline & Japan & 1.20 & 0.10 & 1.50 & 8.40 & 0.40 & 0.90 & 8.70 & 1.40 & 15.20 & 58.90 & 3.30 \\
\hline \multirow{10}{*}{1975} & Indonesia & 16.50 & 71.30 & 3.40 & 0.10 & 0.50 & 0.10 & 6.00 & 0.00 & 1.20 & 0.80 & 0.10 \\
\hline & Malaysia & 33.30 & 8.50 & 19.30 & 2.30 & 7.00 & 0.20 & 4.50 & 0.30 & 13.30 & 10.40 & 0.90 \\
\hline & Philippines & 23.70 & 11.40 & 42.40 & 3.10 & 4.20 & 0.10 & 2.80 & 1.50 & 2.00 & 1.00 & 7.90 \\
\hline & Singapore & 14.60 & 1.50 & 6.20 & 4.90 & 2.80 & 0.80 & 37.10 & 0.60 & 1.90 & 27.20 & 2.50 \\
\hline & Thailand & 42.40 & 3.80 & 31.40 & 6.50 & 2.30 & 0.20 & 1.50 & 1.30 & 5.50 & 2.10 & 2.90 \\
\hline & Brunei & 0.00 & 96.10 & 0.00 & 0.00 & 0.00 & 0.00 & 3.90 & 0.00 & 0.00 & 0.00 & 0.00 \\
\hline & Hong Kong & 3.10 & 4.00 & 2.10 & 46.00 & 0.30 & 1.10 & 6.90 & 0.50 & 0.60 & 25.10 & 10.40 \\
\hline & Korea & 8.90 & 1.30 & 5.10 & 40.50 & 4.80 & 1.00 & 8.10 & 2.10 & 4.70 & 19.10 & 4.20 \\
\hline & Taiwan & 5.10 & 0.06 & 11.23 & 27.82 & 3.79 & 4.29 & 3.05 & 0.96 & 2.31 & 2.49 & 38.92 \\
\hline & Japan & 0.50 & 0.20 & 1.10 & 6.30 & 0.20 & 1.00 & 10.00 & 1.20 & 19.20 & 57.50 & 2.80 \\
\hline \multirow{10}{*}{1980} & Indonesia & 18.40 & 67.60 & 2.20 & 0.70 & 1.50 & 0.00 & 5.80 & 0.10 & 2.80 & 0.70 & 0.20 \\
\hline & Malaysia & 7.90 & 24.80 & 12.90 & 2.70 & 6.50 & 0.10 & 2.40 & 0.20 & 9.30 & 12.30 & 0.80 \\
\hline & Philippines & 11.20 & 18.00 & 27.50 & 7.10 & 6.40 & 0.20 & 2.80 & 1.10 & 3.40 & 4.30 & 18.10 \\
\hline & Singapore & 11.30 & 1.10 & 5.60 & 4.30 & 2.70 & 0.60 & 32.60 & 0.50 & 2.80 & 30.20 & 8.20 \\
\hline & Thailand & 33.90 & 3.90 & 24.20 & 10.00 & 1.10 & 0.20 & 1.90 & 0.50 & 12.90 & 7.50 & 3.90 \\
\hline & Brunei & 0.00 & 94.00 & 0.00 & 0.00 & 0.00 & 0.00 & 5.90 & 0.00 & 0.00 & 0.00 & 0.00 \\
\hline & Hong Kong & 0.60 & 0.30 & 1.00 & 43.40 & 0.10 & 1.40 & 3.10 & 0.40 & 0.50 & 34.40 & 14.90 \\
\hline & Korea & 5.30 & 0.50 & 2.70 & 35.80 & 2.80 & 0.90 & 9.00 & 2.40 & 10.10 & 27.20 & 3.30 \\
\hline & Taiwan & 2.48 & 0.04 & 6.73 & 22.61 & 4.10 & 4.35 & 4.09 & 1.93 & 2.00 & 4.35 & 47.31 \\
\hline & Japan & 0.50 & 0.30 & 1.00 & 4.70 & 0.10 & 0.80 & 8.30 & 1.40 & 13.40 & 66.60 & 3.00 \\
\hline \multirow{10}{*}{1986} & Indonesia & 17.00 & 51.60 & 2.50 & 5.70 & 9.60 & 0.20 & 8.10 & 0.40 & 3.50 & 1.10 & 0.40 \\
\hline & Malaysi & 20.40 & 21.50 & 12.60 & 4.60 & 5.20 & 0.30 & 4.80 & 0.40 & 2.70 & 26.60 & 0.90 \\
\hline & Philippines & 13.00 & 5.80 & 15.60 & 7.60 & 4.60 & 0.30 & 6.80 & 0.40 & 4.90 & 11.20 & 29.90 \\
\hline & Singapore & 7.20 & 0.60 & 4.30 & 5.10 & 1.60 & 1.20 & 27.30 & 0.30 & 2.20 & 42.90 & 7.30 \\
\hline & Thailand & 27.50 & 4.60 & 24.60 & 17.30 & 1.20 & 0.60 & 3.50 & 0.70 & 2.60 & 13.00 & 4.50 \\
\hline & Brunei & - & & 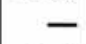 & & & & - & - & - & - & \\
\hline & Hong Kong & 3.30 & 1.00 & 2.40 & 38.00 & 0.20 & 1.50 & 7.20 & 0.70 & 1.40 & 32.80 & 11.40 \\
\hline & Korea & 3.90 & 0.20 & 1.40 & 32.80 & 0.30 & 0.70 & 7.80 & 1.30 & 6.10 & 40.90 & 4.60 \\
\hline & Taiwan & 1.68 & 0.02 & 4.89 & 18.31 & 3.82 & 4.46 & 3.71 & 1.98 & 1.76 & 5.92 & 53.45 \\
\hline & Japan & 0.30 & 0.20 & 0.60 & 3.20 & 0.10 & 0.80 & 7.30 & 1.10 & 6.80 & 77.20 & 2.60 \\
\hline
\end{tabular}

Notes: Data sources and the coding for commodity groups are the same as for Table 3 . 
world exports, because $X_{k}^{i}=X_{k} \cdot S_{k}^{i}$. Since the U.N. yearbook does not contain data for Taiwan, R.O.C, we have supplemented the related data from source 3 . It should be noted here that only those countries having a total export value of more than U.S.\$5000 million are taken into account in the calculations.

Table 2 provides the export share of each commodity group in the countries of the East Asia Ten. There are 11 groups of commodities, and the codings for the commodity groups are 1 for agriculture, 2 for mining and quarries, 31 for food, bev. \& tobacco, 32 for textiles, 33 for wood \& products, 34 for paper \& products, 35 for chemicals, 36 for non-metal mining, 37 for basic metals, 38 for metal manuf. and 39 for other manufactures.

Table 3 presents the share of each commodity group in the total exports of the world, and the selected groups of ASEAN, the East Asia Nine (EA-9), East Asia Ten and the Asian NICs. The EA-9 includes the six countries of ASEAN and the other three NICS - Taiwan, Korea and Hong Kong. For the EA-10 we have included Japan into the EA-9. Mathematically, the export share of a given industry in a grouping is the weighted average of the shares of the member countries. Thus, table 3 is derived from table 2 .

Tables 4 and 5, generated from Tables 2 and 3, respectively, by using formula (3), give the corresponding RCA index for the ten countries and selected groups.

\section{B. On the Degree of Trade Creation}

As mentioned earlier, trade creation, equivalent to an increase in intraregional trade, is positively related to the diversity of export structure or variance of the RCA indices among the member countries. ${ }^{5}$ In that sense, we first attempt to find out the differences in the export structures among countries or groups. Since ASEAN is already organized and Japan has an

5. The positive relationship between the RCA variance and trade creation still holds even if intra-industry trade takes place. Theoretically, we can treat products with different features in the same industry as different goods. For example, big cars can be distinguished from small ones. Depending on the availability of trade data, differences in the RCA indices would imply a high degree of trade creation in each particular industry. 
Table 3

Share of Commodity Groups in the Exports of a Region

(Unit:\%)

\begin{tabular}{|c|c|c|c|c|c|c|c|c|c|c|c|c|}
\hline \multicolumn{2}{|c|}{ Region year } & 1 & 2 & 31 & 32 & 33 & 34 & 35 & 36 & 37 & 38 & 39 \\
\hline World & $\begin{array}{l}1973 \\
1975 \\
1980 \\
1986\end{array}$ & $\begin{array}{l}9.43 \\
8.07 \\
7.29 \\
5.42\end{array}$ & $\begin{array}{l}4.78 \\
6.34 \\
8.10 \\
4.68\end{array}$ & $\begin{array}{l}7.79 \\
7.49 \\
7.20 \\
6.28\end{array}$ & $\begin{array}{l}8.69 \\
7.20 \\
7.02 \\
7.72\end{array}$ & $\begin{array}{l}1.95 \\
1.16 \\
1.35 \\
1.18\end{array}$ & $\begin{array}{l}3.39 \\
3.32 \\
3.02 \\
3.19\end{array}$ & \begin{tabular}{|l|}
12.18 \\
13.14 \\
14.88 \\
14.15
\end{tabular} & $\begin{array}{l}1.52 \\
1.44 \\
1.50 \\
1.44\end{array}$ & $\begin{array}{l}8.38 \\
8.55 \\
7.65 \\
5.48\end{array}$ & \begin{tabular}{|l|}
38.86 \\
40.52 \\
38.40 \\
45.78 \\
\end{tabular} & $\begin{array}{l}3.02 \\
2.77 \\
3.60 \\
4.67\end{array}$ \\
\hline ASEAN & $\begin{array}{l}1973 \\
1975 \\
1980 \\
1985\end{array}$ & $\begin{array}{l}36.83^{\star} \\
21.77^{\star} \\
17.88^{\star} \\
12.56\end{array}$ & $\begin{array}{l}16.80^{*} \\
30.52^{*} \\
34.44^{*} \\
29.76^{*}\end{array}$ & \begin{tabular}{|r|}
10.96 \\
14.41 \\
8.83 \\
9.17
\end{tabular} & $\begin{array}{l}3.81 \\
2.66 \\
3.30 \\
4.85\end{array}$ & $\begin{array}{l}5.74 \\
2.78 \\
2.96 \\
3.54\end{array}$ & $\begin{array}{l}0.43 \\
0.29 \\
0.21 \\
0.39\end{array}$ & $\begin{array}{r}9.77 \\
12.20 \\
11.73 \\
13.40\end{array}$ & $\begin{array}{l}0.48 \\
0.52 \\
0.33 \\
0.34\end{array}$ & $\begin{array}{l}4.75 \\
3.92 \\
4.73 \\
3.54\end{array}$ & \begin{tabular}{|c|}
8.34 \\
8.86 \\
11.43 \\
$17.37^{\star}$
\end{tabular} & $\begin{array}{l}2.09 \\
2.07 \\
4.16 \\
5.08\end{array}$ \\
\hline Sing & $\begin{array}{l}1973 \\
1975 \\
1980 \\
1986\end{array}$ & $\begin{array}{r}23.00 \\
14.60 \\
11.30 \\
7.0\end{array}$ & $\begin{array}{l}1.50 \\
1.10 \\
0.60\end{array}$ & $\begin{array}{l}6.10 \\
6.20 \\
5.60 \\
4.30\end{array}$ & $\begin{array}{l}7.90 \\
4.90 \\
4.30 \\
5.10\end{array}$ & $\begin{array}{l}6.20 \\
2.80 \\
2.70 \\
1.60\end{array}$ & $\begin{array}{l}1.00 \\
0.80 \\
0.60 \\
1.20\end{array}$ & $\begin{array}{l}24.70^{\star} \\
37.10^{*} \\
32.60^{\star} \\
27.30^{\star}\end{array}$ & $\begin{array}{l}0.40 \\
0.60 \\
0.50 \\
0.30\end{array}$ & $\begin{array}{l}1.40 \\
1.90 \\
2.80 \\
2.20\end{array}$ & $\begin{array}{l}25.90^{\star} \\
27.20^{\star} \\
30.20^{\star} \\
42.90^{\star}\end{array}$ & $\begin{array}{l}2.70 \\
2.50 \\
8.20 \\
7.30\end{array}$ \\
\hline $\begin{array}{l}\text { NICs Three: } \\
\text { (Taiwan, } \\
\text { Hong-Kong } \\
\text { and Korea) }\end{array}$ & $\begin{array}{l}1973 \\
1975 \\
1980 \\
1986\end{array}$ & $\begin{array}{l}3.40 \\
5.54 \\
2.69 \\
2.90\end{array}$ & $\begin{array}{l}0.64 \\
1.89 \\
0.27 \\
0.39\end{array}$ & \begin{tabular}{l|l}
4.74 \\
5.98 \\
3.51 \\
2.99
\end{tabular} & $\begin{array}{l}40.96^{\star} \\
38.42^{\star} \\
33.84^{*} \\
29.23^{\star}\end{array}$ & $\begin{array}{l}4.27 \\
2.82 \\
2.32 \\
1.54\end{array}$ & $\begin{array}{l}3.51 \\
2.10 \\
2.27 \\
2.32\end{array}$ & $\begin{array}{l}3.85 \\
6.03 \\
5.25 \\
6.13\end{array}$ & $\begin{array}{l}0.87 \\
1.14 \\
1.54 \\
1.35\end{array}$ & $\begin{array}{l}2.35 \\
2.42 \\
3.97 \\
3.01\end{array}$ & \begin{tabular}{l|}
14.03 \\
15.93 \\
21.75 \\
$25.63^{\star}$
\end{tabular} & $\begin{array}{l}21.40^{*} \\
17.71^{*} \\
22.59^{*} \\
24.50\end{array}$ \\
\hline Japan & $\begin{array}{l}1973 \\
1975 \\
1980 \\
1986\end{array}$ & $\begin{array}{l}1.20 \\
0.50 \\
0.50 \\
0.30\end{array}$ & $\begin{array}{l}0.10 \\
0.30 \\
0.20\end{array}$ & $\begin{array}{l}1.50 \\
1.10 \\
1.00 \\
0.60\end{array}$ & $\begin{array}{l}8.40 \\
6.30 \\
4.70 \\
3.20\end{array}$ & $\begin{array}{l}0.40 \\
0.20 \\
0.10 \\
0.10\end{array}$ & $\begin{array}{l}0.90 \\
1.00 \\
0.80 \\
0.80\end{array}$ & $\begin{array}{r}8.70 \\
10.00 \\
8.30 \\
7.30^{\star}\end{array}$ & $\begin{array}{l}1.40 \\
1.20 \\
1.40 \\
1.10\end{array}$ & $\begin{array}{c}15.20^{\star} \\
19.20^{\star} \\
13.40^{\star} \\
6.80\end{array}$ & $\begin{array}{l}58.90^{*} \\
57.50^{*} \\
66.60^{*} \\
77.20^{*}\end{array}$ & $\begin{array}{l}3.30 \\
2.80 \\
3.00 \\
2.60\end{array}$ \\
\hline
\end{tabular}

Notes: 1 . The code for commodity groups are : 1 . agriculture, 2 mining quarries, 31 . food, bev. $\&$ tobacco, 32. textiles, 33. wood \& products, 34. paper \& products, 35. chemicals, 36 . non-metal min. 37. basic metals, 38 . metal manuf, and 39 for other manufactures.

2. The superscript * denotes the top two $\%$ in a row (corresponding to the two leading exports for a year).

Data Sources: 1. United Nations, 1979-1987, Yearbook of International Trade Statistics (volume 1), Special Table A and Country Tables.

2. Council for Economic Planning and Development, Taiwan Statistical Data Book, R.O.C. 1989.

entirely different export structure pattern from those of the NICs, our discussion is based on three sub-groups, that is, ASEAN, Japan and the NICs.

\section{Intra-ASEAN TC}

From Table 2, it can be seen that highly different export structures exist among the six ASEAN countries. Taking 1986 as an example, the leading 
Deng-Shing Huang and Jenn-Hwa Tu

Table 4

RCA Indices by Countries

\begin{tabular}{|c|c|c|c|c|c|c|c|c|c|c|c|c|}
\hline & Countries & 1 & 2 & 31 & 32 & 33 & 34 & 35 & 36 & 37 & 38 & 39 \\
\hline \multirow{10}{*}{1973} & Indonesia & 4.11 & 9.30 & 0.51 & 0.02 & 0.31 & 0.00 & 0.62 & 0.00 & 0.36 & 0.03 & 0.10 \\
\hline & Malaysia & 5.51 & 0.69 & 1.26 & 0.18 & 5.91 & 0.06 & 0.33 & 0.13 & 1.49 & 0.11 & 0.23 \\
\hline & Philippines & 3.57 & 3.80 & 3.64 & 0.26 & 3.96 & 0.21 & 0.12 & 0.92 & 0.07 & 0.02 & 1.52 \\
\hline & Singapore & 2.44 & 0.15 & 0.78 & 0.91 & 3.19 & 0.30 & 2.03 & 0.26 & 0.17 & 0.67 & 0.89 \\
\hline & Thailand & 5.04 & 0.88 & 2.68 & 0.99 & 1.49 & 0.06 & 0.17 & 0.79 & 0.84 & 0.02 & 1.52 \\
\hline & Brunei & 0.01 & 20.42 & 0.00 & 0.00 & 0.05 & 0.00 & 0.17 & 0.00 & 0.00 & 0.00 & 0.00 \\
\hline & Hong Kong & 0.10 & 0.13 & 0.14 & 5.94 & 0.21 & 0.32 & 0.39 & 0.20 & 0.06 & 0.59 & 5.23 \\
\hline & Korea & 0.64 & 0.29 & 0.45 & 4.91 & 5.34 & 0.44 & 0.44 & 0.92 & 0.73 & 0.43 & 1.66 \\
\hline & Taiwan & 0.46 & 0.03 & 1.25 & 3.18 & 2.18 & 2.26 & 0.14 & 0.73 & 0.21 & 0.05 & 13.09 \\
\hline & Japan & 0.13 & 0.02 & 0.19 & 0.97 & 0.21 & 0.27 & 0.71 & 0.92 & 1.81 & 1.52 & 1.09 \\
\hline \multirow{10}{*}{1975} & Indonesia & 2.04 & 11.25 & 0.45 & 0.01 & 0.43 & 0.03 & 0.46 & 0.00 & 0.14 & 0.02 & 0.04 \\
\hline & Malaysia & 4.13 & 1.34 & 2.58 & 0.32 & 6.05 & 0.06 & 0.34 & 0.21 & 1.55 & 0.26 & 0.32 \\
\hline & Philippines & 2.94 & 1.80 & 5.66 & 0.43 & 3.63 & 0.03 & 0.21 & 1.04 & 0.23 & 0.02 & 2.85 \\
\hline & Singapore & 1.81 & 0.24 & 0.83 & 0.68 & 2.42 & 0.24 & 2.82 & 0.42 & 0.22 & 0.67 & 0.90 \\
\hline & Thailand & 5.25 & 0.60 & 4.19 & 0.90 & 1.99 & 0.06 & 0.11 & 0.90 & 0.64 & 0.05 & 1.05 \\
\hline & Brunei & 0.00 & 15.17 & 0.00 & 0.00 & 0.00 & 0.00 & 0.30 & 0.00 & 0.00 & 0.00 & 0.00 \\
\hline & Hong Kong & 0.38 & 0.63 & 0.28 & 6.39 & 0.26 & 0.33 & 0.53 & 0.35 & 0.07 & 0.62 & $2 \times 75$ \\
\hline & Korea & 1.10 & 0.21 & 0.68 & 5.63 & 4.15 & 0.30 & 0.62 & 1.46 & 0.55 & 0.47 & 1.52 \\
\hline & Taiwan & 0.63 & 0.01 & 1.50 & 3.86 & 3.27 & 1.29 & 0.23 & 0.67 & 0.27 & 0.06 & 14.04 \\
\hline & Japan & 0.06 & 0.03 & 0.15 & 0.88 & 0.17 & 0.30 & 0.76 & 0.83 & 2.24 & 1.42 & 1.01 \\
\hline \multirow{10}{*}{1980} & Indonesia & 2.52 & 8.35 & 0.31 & 0.10 & 1.11 & 0.00 & 0.39 & 0.07 & 0.37 & 0.02 & 0.06 \\
\hline & Malaysia & 3.83 & 3.06 & 1.79 & 0.38 & 4.81 & 0.03 & 0.16 & 0.13 & 1.22 & 0.32 & 0.22 \\
\hline & Philippines & 1.54 & 2.22 & 3.82 & 1.01 & 4.74 & 0.07 & 0.19 & 0.73 & 0.44 & 0.11 & 5.03 \\
\hline & Singapore & 1.55 & 0.14 & 0.78 & 0.61 & 2.00 & 0.20 & 2.19 & 0.33 & 0.37 & 0.79 & 2.28 \\
\hline & Thailand & 4.65 & 0.48 & 3.36 & 1.43 & 0.81 & 0.07 & 0.13 & 0.33 & 1.69 & 0.20 & 1.08 \\
\hline & Brune & 0.00 & 11.61 & 0.00 & 0.00 & 0.00 & 0.00 & 0.40 & 0.00 & 0.00 & 0.00 & 0.00 \\
\hline & Hong Kong & 0.08 & 0.04 & 0.14 & 6.18 & 0.07 & 0.46 & 0.21 & 0.27 & 0.07 & 0.90 & 4.14 \\
\hline & Korea & 0.73 & 0.06 & 0.37 & 5.10 & 2.07 & 0.30 & 0.61 & 1.60 & 1.32 & 0.71 & 0.92 \\
\hline & Taiwan & 0.34 & 0.00 & 0.93 & 3.22 & 3.04 & 1.44 & 0.27 & 1.29 & 0.26 & 0.11 & 13.15 \\
\hline & Japan & 0.07 & 0.04 & 0.14 & 0.67 & 0.07 & 0.26 & 0.56 & 0.93 & 1.75 & 1.73 & 0.83 \\
\hline \multirow{10}{*}{1986} & Indonesia & 3.14 & 11.02 & 0.40 & 0.74 & 8.14 & 0.06 & 0.57 & 0.28 & 0.64 & 0.02 & 0.09 \\
\hline & Malaysia & 3.76 & 4.59 & 2.01 & 0.60 & 4.41 & 0.09 & 0.34 & 0.28 & 0.49 & 0.58 & 0.19 \\
\hline & Philippines & 2.40 & 1.24 & 2.48 & 0.98 & 3.90 & 0.09 & 0.48 & 0.28 & 0.89 & 0.24 & 6.40 \\
\hline & Singapore & 1.33 & 0.13 & 0.68 & 0.66 & 1.36 & 0.38 & 1.93 & 0.21 & 0.40 & 0.94 & 1.56 \\
\hline & Thailand & 5.08 & 0.98 & 3.92 & 2.24 & 1.02 & 0.19 & 0.25 & 0.49 & 0.47 & 0.28 & 0.96 \\
\hline & Brunei & 0.00 & 0.00 & 0.00 & 0.00 & 0.00 & 0.00 & 0.00 & 0.00 & 0.00 & 0.00 & 0.00 \\
\hline & Hong Kong & 0.61 & 0.21 & 0.38 & 4.92 & 0.17 & 0.47 & 0.51 & 0.49 & 0.26 & 0.72 & 2.44 \\
\hline & Korea & 0.72 & 0.04 & 0.22 & 4.25 & 0.25 & 0.22 & 0.55 & 0.90 & 1.11 & 0.89 & 0.98 \\
\hline & Taiwan & 0.31 & 0.00 & 0.78 & 2.37 & 3.24 & 1.40 & 0.26 & 1.38 & 0.32 & 0.13 & 11.44 \\
\hline & Japan & 0.06 & 0.04 & 0.10 & 0.41 & 0.08 & 0.25 & 0.52 & 0.76 & 1.24 & 1.69 & 0.56 \\
\hline
\end{tabular}

Data sources: same as for Table 3. 
commodity groups in the ASEAN countries' exports are good 2 (mining and quarrying, with export share of $51.6 \%$ ) for Indonesia, good 38 (metal manufactures, 26.6\%), 2 (mining and quarrying, 21.5\%) and 1 (agriculture, 20.4\%) for Malaysia, good 39 (other manufactures, 29.9\%) for the Philippines, good 39 (metal manufactured goods, $42.9 \%$ ) and 35 (chemicals, 27.3\%) for Singapore, good 1 (agriculture, 27.5\%) and 31 (food, beverages and tobacco, 24.6\%) for Thailand. For Brunei we use 1985 data and $97 \%$ of its exports consist of good 2 (mining and quarrying). ${ }^{6}$

Generally speaking, the export structures among ASEAN countries are very heterogeneous. In particular, Singapore and Brunei are extremely different from other ASEAN members. Singapore is more similar to the other three NICs than to the other ASEAN countries. Brunei, relying mainly on mining exports, is quite peculiar in East Asia.

Based on the differences in export structure among ASEAN members, we would expect to find a significant trade creation effect, provided that trade barriers within the union are effectively removed. ${ }^{\text {. }}$

\section{ASEAN and the NICs (East Asia Nine)}

In Table 3, the two leading export goods for each group are asterisked. Obviously, ASEAN and the NICs are entirely different in terms of their leading exports. These are good 1 (agriculture) and 2 (mining and quarries) for ASEAN, good 35 (chemicals) and 38 (metal manufactures) for Singapore, and good 32 (textiles) and 39 (other manufactures) for the other three NICs.

These findings are also supported by Table 5 . As noted earlier, a $R C A_{k}^{i}$ that is greater than one implies a revealed comparative advantage of good $i$ for country or region $k$. Table 5 shows that comparatively advantageous

6. Brunei's data for 1986 is not reported in the U.N. yearbook. However, we can use the 1985 data (not reported in Table 3) for discussion purposes, provided that the country's export structure has been fairly stable.

7. However, only limited intra-ASEAN TC effects have been found in existing studies. As cited in Wong [1988], Nays [1977] and Tin [1981] found that "the real impact of PTAs (Preferential Tariff Agreements) on intra-ASEAN TC remains very limited, having been variously estimated to range between 1 and 5 per cent." The limited tariff removing strategies adopted by ASEAN should be the main reason for the failure of TC. 
Table 5

RCA Indices of Different Groups

\begin{tabular}{|c|c|c|c|c|c|c|c|c|c|c|c|c|}
\hline \multicolumn{2}{|c|}{ Region year } & 1 & 2 & 31 & 32 & 33 & 34 & 35 & 36 & 37 & 38 & 39 \\
\hline \multirow{4}{*}{ ASEAN } & 1973 & 3.91 & 3.51 & 1.41 & 0.44 & 2.95 & 0.13 & 0.80 & 0.31 & 0.57 & 0.21 & 0.69 \\
\hline & 1975 & 2.70 & 4.82 & 1.92 & 0.37 & 2.40 & 0.09 & 0.93 & 0.36 & 0.46 & 0.22 & 0.75 \\
\hline & 1980 & 2.45 & 4.25 & 1.23 & 0.47 & 2.19 & 0.07 & 0.79 & 0.22 & 0.62 & 0.30 & 1.16 \\
\hline & 1985 & 2.08 & 3.78 & 1.51 & 0.69 & 3.13 & 0.13 & 0.90 & 0.26 & 0.59 & 0.41 & 1.20 \\
\hline \multirow{4}{*}{ Singapore } & 1973 & 2.44 & 0.15 & 0.78 & 0.91 & 3.19 & 0.30 & 2.03 & 0.26 & 0.17 & 0.67 & 0.89 \\
\hline & 1975 & 1.81 & 0.24 & 0.83 & 0.68 & 2.42 & 0.24 & 2.82 & 0.42 & 0.22 & 0.67 & 0.90 \\
\hline & 1980 & 1.55 & 0.14 & 0.78 & 0.61 & 2.00 & 0.20 & 2.19 & 0.33 & 0.37 & 0.79 & 2.28 \\
\hline & 1986 & 1.33 & 0.13 & 0.68 & 0.66 & 1.36 & 0.38 & 1.93 & 0.21 & 0.40 & 0.94 & 1.56 \\
\hline \multirow{4}{*}{$\begin{array}{l}\text { NIC 3 (Taivan, } \\
\text { Hong Kong and } \\
\text { Korea) }\end{array}$} & 1973 & 0.36 & 0.13 & 0.61 & 4.71 & 2.19 & 1.03 & 0.32 & 0.57 & 0.28 & 0.36 & 7.08 \\
\hline & 1975 & 0.69 & 0.30 & 0.80 & 5.34 & 2.44 & 0.63 & 0.46 & 0.80 & 0.28 & 0.39 & 6.39 \\
\hline & 1980 & 0.37 & 0.03 & 0.49 & 4.82 & 1.72 & 0.75 & 0.35 & 1.03 & 0.52 & 0.57 & 6.28 \\
\hline & 1986 & 0.54 & 0.08 & 0.48 & 3.79 & 1.31 & 0.73 & 0.43 & 0.94 & 0.55 & 0.56 & 5.24 \\
\hline \multirow{4}{*}{ NICs } & 1973 & 0.82 & 0.14 & 0.65 & 3.86 & 2.41 & 0.87 & 0.70 & 0.50 & 0.26 & 0.43 & 5.70 \\
\hline & 1975 & 0.96 & 0.28 & 0.81 & 4.19 & 2.43 & 0.54 & 1.04 & 0.70 & 0.27 & 0.46 & 5.03 \\
\hline & 1980 & 0.67 & 0.06 & 0.56 & 3.76 & 1.79 & 0.61 & 0.82 & 0.85 & 0.48 & 0.62 & 5.27 \\
\hline & 1986 & 0.67 & 0.09 & 0.51 & 3.26 & 1.32 & 0.67 & 0.69 & 0.82 & 0.52 & 0.62 & 4.62 \\
\hline \multirow{4}{*}{$\begin{array}{l}\text { EA-9 } \\
\text { (ASEAN + } \\
\text { NICs-3) }\end{array}$} & 1973 & 2.19 & 1.88 & 1.02 & 2.50 & 2.58 & 0.57 & 0.57 & 0.44 & 0.43 & 0.29 & 3.78 \\
\hline & 1975 & 1.85 & 2.91 & 1.45 & 2.46 & 2.42 & 0.32 & 0.73 & 0.54 & 0.38 & 0.29 & 3.12 \\
\hline & 1980 & 1.54 & 2.40 & 0.90 & 2.38 & 1.98 & 0.37 & 0.60 & 0.58 & 0.57 & 0.42 & 3.40 \\
\hline & 1986 & 1.39 & 1.45 & 0.85 & 2.72 & 2.20 & 0.53 & 0.62 & 0.70 & 0.54 & 0.54 & 3.75 \\
\hline \multirow{4}{*}{ Japan } & 1973 & 0.13 & 0.02 & 0.19 & 0.97 & 0.21 & 0.27 & 0.71 & 0.92 & 1.81 & 1.52 & 1.09 \\
\hline & 1975 & 0.06 & 0.03 & 0.15 & 0.88 & 0.17 & 0.30 & 0.76 & 0.83 & 2.24 & 1.42 & 1.01 \\
\hline & 1980 & 0.07 & 0.04 & 0.14 & 0.67 & 0.07 & 0.26 & 0.56 & 0.93 & 1.75 & 1.73 & 0.83 \\
\hline & 1986 & 0.06 & 0.04 & 0.10 & 0.41 & 0.08 & 0.25 & 0.52 & 0.76 & 1.24 & 1.69 & 0.56 \\
\hline \multirow{4}{*}{$\begin{array}{l}\text { East Asia } 10 \\
\text { (EA-9+ Japan) }\end{array}$} & 1973 & 0.99 & 0.80 & 0.54 & 1.61 & 1.20 & 0.39 & 0.65 & 0.72 & 1.24 & 1.00 & 2.21 \\
\hline & 1975 & 0.80 & 1.21 & 0.68 & 1.53 & 1.10 & 0.31 & 0.75 & 0.72 & 1.48 & 0.96 & 1.88 \\
\hline & 1980 & 0.80 & 1.22 & 0.52 & 1.52 & 1.03 & 0.32 & 0.58 & 0.75 & 1.16 & 1.07 & 2.12 \\
\hline & 1986 & 0.66 & 0.68 & 0.44 & 1.46 & 1.04 & 0.38 & 0.56 & 0.73 & 0.92 & 1.16 & 2.01 \\
\hline
\end{tabular}

Sources: same as for Table 3.

products for ASEAN are good 1 (agriculture), 2 (mining), 31 (food, beverages and tobacco) and 33 (wood and related products). For the other three NICs they are good 32 (textiles), 33 (wood and related products) and 39 (other manufactures). Except in the case of good 33 (wood and related 
products), ASEAN and the three NICs have revealed comparative advantages in different goods.

In sum, there is a high degree of difference in terms of export structure and comparative advantage between ASEAN and other three NICs. Thus we would expect a large trade creation if ASEAN and NICs were to remove their trade barriers.

\section{East Asia and Japan (East Asia Ten)}

What would happen if Japan were to be included in these groups? To answer this question, we compare the export structure of Japan with those of ASEAN and the NICs. As noted before, a difference in export structures leads to trade creation. Table 3 shows that the two leading export commodities for Japan are good 38 (metal manufactures), and 37 (basic metals). These are almost entirely different from those of ASEAN and the NICs. ${ }^{8}$

Table 5 also shows that Japan has a revealed comparative advantage in metal manufactures and basic metals, its two leading exports. Neither ASEAN nor the NICs have a revealed comparative advantage in these two industries. On the other hand, industries in which ASEAN and the NICs have a comparative advantage, are not ones in which Japan has a revealed comparative advantage. Thus, if Japan is included in the union, we would expect high TC effects between Japan and the East Asia Nine in the case of goods 1, 2, 31, 33 and 39 exported to Japan, and goods 37,38 exported from Japan to the East Asia Nine. That is to say, agriculture products, mining, food, beverages and tobacco, textiles and other manufactures are exported to Japan and basic metals and metal manufactures are exported from Japan.

\section{On the Degree of Trade Diversion}

Trade diversion comes as a result of higher-cost products from member countries replacing cheaper imports from outside the region. We would expect trade diversion to occur, if it is revealed that comparative advantage

8. Although commodity 38 (metal manufactures) is also one of the two leading exports for Singapore, the RCA indices in Table 5 show that only Japan has a revealed comparative advantage in the case of this commodity. 
exists for the rest of the world (ROW). Clearly, member countries that suffer from TD are those that import the higher cost products, or equivalently, those which have a comparative disadvantage over them. In other words, a member country that has a low RCA index would probably suffer from a trade diversion, if the union as a whole had a revealed comparative disadvantage.

In that sense, we calculate the RCA indices for ROW or equivalently for the group of countries as a whole. ${ }^{9}$ Again we first discuss the grouping of ASEAN and the NICs, and then the case in which Japan is included.

\section{East Asia Nine}

As for the East Asia Nine, in Table 5, the RCA indices of the nine countries as a whole are provided in panel 5 . In 1986, goods 34,37 , and 38 had RCA indices substantially below one, that is $.53, .54$ and .54 respectively. In other words, the nine countries as a whole had a revealed comparative disadvantage in these goods. Any economic union with discriminatory trade policies against the outside world would cause them to suffer from a trade diversion in these commodities.

According to the RCA indices for 1986 in Table 4, the East Asian countries, except for Taiwan, would suffer from a TD in the case of good 34, paper and paper products. In the case of good 37, basic metals, Malaysia, Singapore, Thailand, Brunei, Hong Kong and Taiwan would suffer (their RCA indices in the commodity group are below .5). For good 38, metal manufactures, the countries that would suffer would be Indonesia, the Philippines, Thailand and Brunei.

\section{East Asia Ten}

If Japan is included in the union, the comparatively disadvantageous goods become goods 31 (food, beverages and tobacco), 34 (paper and paper products) and 35 (chemicals).

It is worth noting that the TD in the case of goods 37 and 38 for the East Asia Nine disappears if Japan is included in the group. The reason for this change is clear. Since Japan has a comparative advantage in goods 37 and

9. If we separate the world into the two regions, a higher RCA for one region would correspond with a lower RCA for the other one. 
$38,{ }^{10}$ excluding Japan from the group will shift the imports from Japan to other member countries and, therefore, TD occur.

Countries having low RCA indices in the case of goods 31,34 and 35 will suffer from a TD by importing them from the other member countries. According to Table 4, they are Indonesia, Brunei, Hong Kong, Korea and Japan in the case of good 31 (food, beverages, and tobacco); all countries, except for Taiwan, in the case of good 34 (paper and paper products); and Malaysia, the Philippines, Thailand, Brunei and Taiwan in the case of good 35 (chemicals).

\section{Concluding Remarks}

For ease of comparison, the findings are summarized as Table 6. By making use of the RCA index, we are able to decompose the effect of the proposed East Asia grouping into two kinds: trade creation and trade diversion. As far as economic gain is concerned, trade creation acts as a force in favor of regionalization, and trade diversion as a deterrent.

We have shown that the export structures differ quite significantly between ASEAN and the NICs. Based on the RCA indices, we would expect an intra-regional trade creation to occur in commodity groups 1 (agriculture), 2 (mining), 31 (food, beverages, and tobacco), 32 (textiles), 33 (wood \& products) and 39 (other manufactures) if ASEAN and the NICs were to form a union. Since Japan has a revealed comparative advantage in commodity groups 37 (basic metals) and 38 (metal manufactures), excluding it from the union would lead to TD in the case of these two goods. Member countries importing these two goods would suffer from this TD.

Thus, if Japan is included into the union, the trade diversion from these two goods, 37 and 38 , disappears. On the other hand, we would expect trade creation to take place between Japan and the East Asia Nine in these two commodity groups. However, for goods 31 (food, beverages and tobacco), 34 (paper and paper products), and 35 (chemicals), in which the ten countries as a whole have a comparative disadvantage as compared with the rest of the world, a TD is inevitable. Again, countries that have to import or have a com-

10. See Table 5 for Japan's RCA index. 
Table 6

TC and TD for Different Groupings

\begin{tabular}{|c|c|c|}
\hline Groupings & $\begin{array}{l}\text { TC-good } \\
\text { (Benefiting group }^{2} \text { ) }\end{array}$ & $\begin{array}{l}\text { TD-good } \\
\text { (Suffering countries }^{3} \text { ) }\end{array}$ \\
\hline EA-Nine & $\begin{array}{l}1,2,31,33 \text { (ASEAN) } \\
32,33,39 \text { (NICs-3) }\end{array}$ & $\begin{array}{l}34 \text { (All except Taiwan) } \\
37 \text { (Mal. Singa. Thai. Bru. HK. Taiwan) } \\
38 \text { (Indo. Phil. Thai. Bru.) }\end{array}$ \\
\hline EA-Ten & $\begin{array}{l}1,2,31,33 \text { (ASEAN) } \\
32,33,39 \text { (NICS) } \\
37,38 \text { (Japan) }\end{array}$ & $\begin{array}{l}31 \text { (Indo. Bru. HK. Kor. Jap.) } \\
34 \text { (All except Taiwan) } \\
35 \text { (Mal. Phil. Thai. Bru. Taiwan) }\end{array}$ \\
\hline
\end{tabular}

Notes: 1 . Codes for commodity groups are the same as for those in Table 3.

2. Benefiting groups are those having RCA $>1$.

3. Suffering countries are those with $\mathrm{RCA}<.5$

Source: Tables 2, 3, 4 and 5.

parative disadvantage in these goods would suffer from a trade diversion.

It may be remarked that we can not draw any conclusion as to whether and how the East Asia countries should integrate, based on the findings by now. This is because that the RCA index can identify only the occurrence rather than the magnitudes of the TC and TD for each of the commodity groups. However, we believe that identifying the TC and TD commodities for all the member countries is essential to understand the feasibility of economic integration, especially when the behavior of interested groups is concerned. In addition, the ex-ante RCA index cannot capture the dynamic effects of regionalization, e.g., scale economies, ${ }^{11}$ an increase in bargaining power, etc., factors which are usually of much concern to member countries. Therefore, further study is needed to measure the dynamic aspects of economic cooperation in East Asia.

\section{References}

Balassa, B. [1961], The Theory of Economic Integration, Homewood, Ill. Richard D. Irwin.

11. El-Agraa [1988, ch.15, p. 332] argues that the most likely benefits of economic integration are essentially those resulting from increasing economies of scale. 
Batra, R.N. [1973], Studies in the Pure Theory of International Trade, New York: St. Martin's Press.

Ben-David, D. [1991] "Equalizing Exchange: A Study of the Effects of Trade Liberalization," NBER Working Paper \# 3706, May.

Bhagwati, J. N. [1971], "Trade-Diverting Customs Unions and Welfare

Improvement: A Clarification," Economic Journal, Vol. 81; pp. 580-587.

Chacholiades, M. [1978], International Trade Theory and Policy, New York: McGraw-Hill .

Choi, J.Y. and E. Yu [1984], "Customs Unions under Increasing Returns to Scale," Economica, Vol. 51; pp. 195-203.

El-Agraa, A.M. [1985] "Measuring the Impact of Economic Integration," in A.M. El-Agraa, ed., The Economics of the European Community, Oxford: Philip Alan Pub. Ltd.; pp. 112-23.

Gehrels, F. [1956], "Customs Unions from a Single Country View-point," Review of Economic Studies, Vol. 24; pp. 61-64.

Hou, C. M. and C. N. Wang [1991] "Globalization and Regionalization - Taiwan's Perspective," Paper Presented at the 1991 Sino-European Conference on Economic Development: Globalization and Regionalization, May 23-May 24, Taipei 1991.

Kreinin, M. [1964], “On the Dynamic effects of a Customs Union,” Journal of Political Economy; pp. 193-195.

Lipsey, R. G. [1957], "The Theory of Customs Union: Trade Diversion and Welfare," Economica, Vol. 24, Feb; pp. 40-46.

Melvin, J. R. [1969], “Comments on the Theory of Customs Unions," Manchester School of Economic and Social Studies, Vol. 37; pp. 161-168.

Miyagiwa, K. F. and L. Young [1986], "International Capital Mobility and Commercial Policy in an Economic Region," Journal of International Economics; pp. 329-341.

Patterson, S. [1986] "Trade Creation and Trade Diversion and Transportation Costs," Atlantic Economic Journal, Dec.; pp. 34-38.

Richard, D. and L. F. S. Wang [1988], "Urban Unemployment and Customs Unions," Academia Economic Paper, Vol. 16; pp. 53-67.

Scitovsky, T. [1958], Economic Theory and Western European Integration, Stanford: University Press.

Scully, G. W. and E. S. H. Yu [1974], "International Investment, Trade Diver- 
sion and Trade Creation," Economic Record, Vol. 50; pp. 600-604.

Viner, J. [1950], The Customs Union Issue, New York: Carnegie Endowment for International Peace.

Webster, A. [1991], "Some Issues in the Measurement of Comparative Advantage," Applied Economics, Vol. 23; pp. 937-948.

Wong, J. [1979], ASEAN Economies in Perspective: a Comparative Study on Indonesia, Malaysia, the Philippines, Singapore and Thailand, London: MacMillan Press Ltd.

Wong, J. [1985] “ASEAN's Experience in Regional Economic Cooperation,” Asian Development Review, Vol. 3, No.1; pp. 79-98.

Wong, J. [1988] "The Association of Southeast Asian Nations," in El-Agraa, A.M. ed. International Economic Integration, Hong Kong: MacMillan Press, Ch. 14; pp. 314-326.

Yu, E. S. H. and G. W. Scully [1975], "Domestic Distortions and the Theory of Customs Unions," Southern Economic Journal, Vol. 42, No. 2; pp. 218-224.

Yu, E. S. H. [1981], "Trade Diversion, Trade Creation and Factor Market Imperfections," Weltwirtschaftiches Archiv, Vol. 117, No. 3; pp. 546-561. Yu, E. S. H. [1982], "Unemployment and the Theory of Customs Unions," Economic Journal, Vol. 92, No. 366; pp. 399-404.

Yu, E. S. H. [1985], "Toward a Theory of Customs Unions with Foreign Investment," Economia Internazionale, Vol. 38; pp. 222-235. 